\title{
Gender Role Attitudes in Germany, 1982-2016: An Age-Period-Cohort (APC) Analysis*
}

\section{Daniel Lois}

\begin{abstract}
The present study investigates the change of gender role attitudes in Germany between 1982 and 2016. Nine waves of the German General Social Survey are used ( $N=26,389$ ). In contrast to previous trend studies, which largely ignore age effects, a mechanism-based age-period-cohort model (Winship/Harding 2008) is applied. It becomes clear that age, period and cohort independently have an impact on gender role ideology. Compared to earlier research, new insights concerning the shape of cohort effects come to light: Specific to traditional gender ideology in Western Germany, it is apparent that the trend towards increasingly egalitarian attitudes comes to a halt in men born around 1956 and later and in women born 1966. For Eastern Germany we observe that the cohort-specific trend towards liberalisation in younger cohorts either is diminishing or even tends to reverse. This pattern of effects mainly mirrors the phases of the feminist movement in Western Germany and the rise and decline of the German Democratic Republic, respectively.
\end{abstract}

Keywords: APC analysis - Identification problem · Sexism - Gender role attitudes · German reunification

\section{Introduction}

Gender role attitudes can, generally speaking, be defined as an individual's norms respective to gender-specific appropriate behaviour (Krampen 1979). If this specifically involves gender-based stereotypes that result in the inequality of men and women, this can be termed sexism (Swim et al. 1995). The traditional role preconception of ascribing the role of wife, mother and career aide for men to women is a typical form of sexism. Research into traditional gender role orientations is societally relevant, since it implies a devaluation of or disadvantage to women: Domestic and family-orientated tasks are, by and large, unpaid, are accorded less social recognition, frequently result in economic dependence and poverty in old age 
among women, and exacerbate their public invisibility and political powerlessness (cf. Mays 2012).

Furthermore, gender role orientations are useful for explaining various demographically relevant attitudes and modes of behaviour and constitute a worthwhile subject of research for this reason as well. Thus, for instance, gender role orientations have an impact on the perceived fairness of the division of domestic work (Greenstein 1996), marital satisfaction (Amato/Booth 1995) or fertility behaviour (Kaufman 2000).

While researching the long-term transformation of gender role orientations, in principle, three temporal dimensions merit consideration: cohort effects, age effects and period effects.

(1) Cohort or socialisation effects cover differences between various generations. This centres on the assumption that individual characteristics such as gender role attitudes are acquired during childhood and youth. The formative phase of socialisation is typified here by various contextual conditions (events, socioeconomic characteristics) and has a lasting influence on the further course of life (Ryder 1965).

(2) Age or life cycle effects relate to changes within birth cohorts that are caused by the status of a person in the life cycle. Chronological ageing is accompanied by biological ageing (physiological changes in the body), social ageing (changes in social relations) and psychological ageing (changes in attitudes, values and dispositions).

(3) Differences between various calendar times that equally concern all cohorts and age groups are designated period effects. They include influences caused by the historical context, such as a typical spirit of the age ("Zeitgeist") or socio-structural changes that exert an impact on individuals (cf. Lois 2011).

Previous studies addressing the development of gender-based attitudes in western industrialised countries (Germany, Luxembourg, USA) have for decades shown that these attitudes are increasingly becoming more egalitarian (Mason/Lu 1988; Braun/A/win 1994; Braun et al. 1994; Brewster/Padavic 2000; Thornton/Young-DeMarco 2001; Brooks/Bolzendahl 2004; Lee et al. 2007; Valentova 2013; Baier 2014). This trend manifests itself, in the first instance, as a cohort effect (cohort replacement): older cohorts and those with traditional attitudes are gradually replaced by younger cohorts with a more liberal orientation. Secondly, a period effect is evident (intra-cohort change): Irrespective of cohort affiliation, more egalitarian gender role orientations are found in more recent survey years. However, specific to the USA, Cotter, Hermsen and Vanneman (2011) observe in a more recent study that the longterm and consistent trend towards increasingly egalitarian gender roles seems to have decreased since the mid-1990s, or in post-baby-boom cohorts (born 1952 or later). According to one hypothesis, this supposed end of the "gender revolution" is a result of a changing popular culture in which aspects of feminist equality and traditional motherhood roles are combined.

Several panel studies have shown that gender role ideology changes in the course of life - for instance during education or after the birth of the first child (Bryant 2003; Crouter et al. 2007; Davis 2007; Katz-Wise et al. 2010; Vespa 2009). However, age effects are largely neglected by previous studies which are based 
on repeated cross-sections. Thus, it cannot be ruled out, for example, that cohort effects reported so far are biased by age-specific variance which is not accurately addressed by the statistical model. This is the backdrop against which, in the following, a trend study on gender role orientations specific to Germany is conducted based on the newest available data of the German General Social Survey (GGSS). The application of a full-fledged Age-Period-Cohort (APC) model which builds on the mechanism-based approach (Winship/Harding 2008) promises new insights on the actual shape of age, period and cohort effects. With regard to Cotter et al. (2011), special attention is paid to the question of whether the trend towards liberalisation has also decreased in the German context.

The paper is structured as follows: Section 2 summarises the current state of research on the change of gender role attitudes in Germany. Section 3 examines the debate on the simultaneous existence of age, period, and cohort effects. Following methodological explanations in Section 4, the APC analyses are presented in Section 5 and finally discussed in Section 6.

\section{The change of gender role attitudes in Germany: The current state of research}

Braun, Alwin and Scott (1994) compare Germany with the United States and assess items in terms of the impact of women's employment on young children and in terms of a traditional gender ideology. Data are based upon the German General Social Survey (GGSS) and, for the USA, the General Social Survey (GSS). For Western Germany, from the early 1980s to the early 1990s, there was a significant shift towards a more pronounced advocacy of egalitarian gender roles. This applies both to women and to men and, in particular, to gender ideology. This German trend towards increasingly egalitarian gender roles took hold earlier than in the United States, and began to diminish as early as the late 1980s. Lee, A/win and Tufis (2007) carry forward the analyses of Braun et al. (1994). They similarly base their study on GGSS data for the review period 1982-2004. Instead of comparing Western Germany and the USA, however, a comparison is drawn between the old federal states (the pre-reunification Federal Republic of Germany FRG) and the new federal states (the former German Democratic Republic GDR). Descriptive analyses show that East German respondents are, at any given point in time, less traditional in their views than West German respondents. Furthermore, it is clear that in both the new federal states (1990-2004) and the old federal states (1982-2004), there is an uninterrupted trend towards increasingly egalitarian gender roles. Linear cohort and period effects are differentiated within the framework of a decomposition analysis (ignoring age). The results indicate that gender ideology in West German men and women has liberalised, especially during the first phase (1982-1991).

Using GGSS data from 2008, Wenzel (2010) concludes that East German respondents still evaluate mother's paid employment more positively than West German respondents do. This difference holds even in multivariate models controlling for age, sex, education, employment status, and religious denomination. 
Baier (2014) investigates the change of gender role attitudes in Germany from 1982-2008 using GGSS data. In descriptive terms, he confirms the trend towards more liberal attitudes from a period-specific and a cohort-specific perspective. Additionally, he tries to estimate a full APC model and finds that age has no additional explanatory power when controlling for period and cohort.

Viewed critically, the studies of Braun et al. (1994), Lee et al. (2007) and Wenzel (2010) have an underfitting problem due to the cross-sectional design (Wenze/ 2010) or the missing of the age effect (Braun et al. 1994, Lee et al. 2007), respectively. The main issue with the APC model estimated by Baier (2014) is that a conventional OLS model is used which potentially is affected by collinearity problems within the APC framework. That is, a simple OLS model is likely to overestimate or underestimate the true age, period and cohort effects in this context.

\section{Changes in gender role attitudes in Germany: An APC approach}

In the following, various factors are outlined which might be the potential causes of specific age, period, and cohort effects. Besides important historical phases, especially the period of German partition, various "megatrends" - such as the expansion of education - are considered.

An important historical factor underlying cohort-specific socialisation effects in Western Germany is the second wave of the New Women's Movement. It emerged in the late 1960s from the student movement and spanned various phases. The first phase was defined by campaigns against abortion law (Paragraph 218 of the German Criminal Code) in the first half of the 1970s; the second phase was characterised by the establishment of encounter groups, and the third phase - from 1977 onwards - by the emergence of numerous feminist projects. The New Women's Movement brought together women with differing ideological standpoints. First and foremost, the radically feminist school of thought is diametrically opposed to traditional gender role orientations and considers its primary task to be fighting patriarchy (Nave-Herz 1997: 75-77).

In the historical context, the influences of the New Women's Movement are considered to have set in from the West German 1946-1950 cohorts onwards. Furthermore, one could cautiously assume that the New Women's Movement was at its height during the 1970s. It is apparent that two counter-movements emerged during the 1980s - simultaneously with US developments. Thus, in the first instance, a new "feminine myth" gained popularity; emphasising the significance of physical experiences such as motherhood, pregnancy, birth, and breastfeeding as the essence of womanhood. The second counter-movement can be termed "new motherliness" and promised women appreciation and personal fulfilment derived from the maternal role (Nave-Herz 1997: 48-51).

After reunification in 1990, the situation was characterised by a drive for more heavily institutionalised women's policy, such as the increase in university-driven research in the field of women's studies and the institutionalisation of equal opportunity legislation. Secondly, the women's movement "individualised" itself to the 
point that it was characterised less by representative organizations or prominent factions than by numerous women's projects and a diverse and colourful "scene". Whether this structural shift, consistent with fragmentation, is associated with a loss of relevance of the women's movement is a controversial issue (Nave-Herz 1997: 73-74; Karl 2011: 240-251).

In contrast to the old FRG, in the GDR - apart from the period immediately prior to the fall of the Berlin Wall - there was no independent grassroots women's movement. Nevertheless, the ideological climate was shaped by the fact that women's equality ranked among the primary objectives of state policy. Along with doing away with class antagonism, the development of socialist polity after the Second World War was also supposed to eliminate antagonism between the sexes. This was reflected, for instance, in a relatively female-friendly GDR constitution, which stipulated equal rights in the family, wage equality for work of equal value, the right to equal education and a ban on discrimination against children born out of wedlock and their parents (Karl 2011: 203-204).

The role model for the GDR's labour market and family policies was the working mother, since women's participation in the development of the socialist state was an economic necessity. Up to the beginning of the 1970s, the promotion of women's employment, which was equated with women's emancipation, was a priority. Specific initiatives ranged from one year's paid maternity leave, the reduction of working hours for mothers, an increase in child benefits, to the expansion of crèches and kindergartens (Karl 2011: 207-208). In 1988, 83 percent of women in the GDR were engaged in paid employment. In the FRG, where the male breadwinner model was, for a long time, considered to be the ideal and was promoted by the state, only 55 percent of women were concomitantly in employment (Pritchard 2003).

Despite women's robust participation in the labour market in the GDR, one cannot speak of complete equality. Female employees were under-represented in positions of leadership and over-represented in low-wage industries. For reasons of compatibility, they often accepted jobs that were below their level of qualification. In societal terms, a patriarchal family model continued to be upheld in the GDR; this apportioned women sole responsibility for the household and the family, thus frequently resulting in a dual burden (Karl 2011: 208-211).

Nevertheless, it can be assumed that the birth cohorts that were socialised in a consolidated GDR state - primarily in the cohorts born between 1940 and 1960 manifest more egalitarian gender role orientations than West German cohorts do.

During the course of reunification, the social position of East German women in particular suffered structural deterioration. In reunified Germany, the employment of mothers was no longer financially promoted on the same scale as in the GDR; the labour market situation worsened - particularly during the first few years following reunification - and childcare facilities became less readily available than they were prior to reunification (Lee et al. 2007). However, qualitative and quantitative studies show that the high level of East German women's orientation towards paid employment has continued over the first decades following reunification (Beck 2003; Arránz Becker et al. 2010). In the new federal states, the labour force participation rate between 1991 and 2000 initially dropped from 77.2 percent to 69.3 percent, 
subsequently rising again to 75.8 percent in the years leading up to 2012. Clear differences between the East and the West are manifest, above all, in employment among mothers: In 2012, 55.7 percent of mothers with children aged below the age of 18 in their household are in full-time employment in the new federal states; in the old federal states, this figure stands at just 25.2 percent (Holst/Wieber 2014).

The consistently robust vocational orientation and employment rates among East German women (particularly mothers) thus lead to the assumption that their relatively egalitarian gender role orientation continued after 1990, i.e. in the postreunification post-1970 cohorts.

Regarding period effects, various "megatrends" which can be attributed to Western industrialised nations have to be considered. General expansion in the realm of education, which commenced in the Federal Republic as far back as the 1950s and lost momentum only in the mid-1990s, is considered to have contributed to the liberalisation of gender role orientations. In relation to birth cohorts, effects of this expansion of education are to be expected from the year 1950 onwards (Becker 2006: 37-40). Closely linked to the expansion of education is women's growing participation in the labour market. For instance, there is a rise in the employment rate among West German women from 54.6 percent (1991) to 67.5 percent (2012) (Ho/st/Wieber 2014). The correlation between women's employment and egalitarian gender roles is a robust finding (e.g., Thornton et al. 1983; Tallichet/Willits 1986; Bolzendahl/Myers 2004; Brooks/Bolzendah/ 2004).

With respect to familial living arrangements, research shows that married people and those with children tend to hold more traditional gender role orientations compared to unmarried, divorced or childless individuals (e.g., Thornton et al. 1983; Tallichet/Willits 1986; Bolzendahl/Myers 2004; Vespa 2009). While in the new federal states the tendency to favour marriage is traditionally modest, since the 1980s, marriage has also become less important in the old federal states. This is borne out, for instance, by marriage later in life, the increasing proportion of nonmarital cohabitation, the increase in extra-marital births and the loss in importance of the institution of marriage at the attitudinal level (for an overview, see Peuckert 2012: 29-46). Regarding fertility behaviour, Bujard and Sulak (2016) show, from a cohort perspective, that the decline in the birth rate in Germany can be explained in terms of two phases: While a decline in higher order births was decisive for women in the years 1933-1947, an increase in childlessness was the key factor for those in the years 1948-1968. From a period perspective, what must also be pointed out here is the rapid drop in fertility in the new federal states during the period under review, particularly evident in the first half of the 1990s (Kreyenfeld 2000).

Finally, evidence pointing to the existence of age effects comes from (rather rare) panel studies which focus on intra-individual changes in the course of important biographical transitions. Regarding primary socialisation, Crouter et al. (2007) find a u-shaped trend for the development of traditional gender role attitudes between ages 7 and 19. However, this general trend is moderated to a substantial degree by parent's traditionalism as well as the gender and the age of siblings (see also Davis 2007). Bryant (2003) shows with respect to secondary socialisation in educational institutions, that traditional gender role attitudes generally decrease within the first 
four years in higher education. The amount of the decline depends on the area of study as well as on the social composition of the peer group. Katz-Wise, Priess and Hyde (2010) find that gender role attitudes, especially those of women, become more traditional after the birth of the first child (see also Vespa 2009).

In general, based on the state of research and the theoretical arguments mentioned above, the conclusion seems to be justified that a full-fledged age-periodcohort model is neccesary to investigate the change of gender role attitudes in Germany.

\section{$4 \quad$ Data and methods}

\subsection{Data and measures}

The analyses are based upon the German General Social Survey (GGSS, GES/S 2016). Since 1980, the GGSS has been collecting data on attitudes, behavioural patterns, and the social structure in Germany in the form of repeated cross-sectional surveys. Questions on gender role orientations have thus far been raised in nine waves: 1982 (Western Germany only), 1991, 1992, 1996, 2000, 2004, 2008, 2012 and 2016. The cumulative sample size is $N=26,389$ persons.

Until 1990, the target population of the GGSS consisted of all adult German nationals living in private households in the Federal Republic of Germany (including West Berlin). From 1991 onwards, the target population consists of all adult German nationals and adults of other nationalities living in private households in the Federal Republic (West and East). Foreign nationals are surveyed only if the interview can be conducted in German. In order to take into account the new definition of the target population, a dummy variable "foreign citizen" is considered in all models $(1=$ yes, $0=$ no). Furthermore, depending on the survey design, those living in multiple-person households also have lower chances of being selected. Because familial living arrangement is used as a standard mediator (see below), all models implicitly control for this issue.

Furthermore, it must be borne in mind that respondents from the new federal states are over-represented in the GGSS. Since there are, concurrently, major East-West differences in gender role orientation (Lee et al. 2007; Mays 2012), all the analyses below are conducted separately for Western Germany and for Eastern Germany. ${ }^{1}$ Finally, gender-specific differences are to be anticipated (Mays 2012). For this reason, all analyses within the area surveyed are conducted separately for men and for women.

1 A restriction of the data lies in the fact that for the East-West classification, merely the current domicile is available, and not the place of birth and socialisation. Due to internal migration between East and West, a classification based on the domicile is becoming increasingly problematic. 
Gender role orientations in the GGSS are surveyed by means of six four-level items, originating from the American General Social Survey (GSS). Respondents are presented with three statements each on traditional gender ideology (henceforth termed TGI) and three statements on the evaluation of mother's paid employment for young children (henceforth termed EMPLOY). The wording of the items can be found in Table $1 .{ }^{2}$ A new version of the questionnaire was introduced in the 2012 and 2016 waves, incorporating partially modified item formulations, using the split-half method. For reasons of comparability, this analysis draws solely upon the original version. For this reason, only half the sample is available in 2012 and 2016.

Tab. 1: Item wordings

Traditional gender ideology (TGI)

"It is much better for everyone if the man is the achiever outside the home and the woman takes care of the home and the family."

"For a woman it is more important to help her husband with his career than to get ahead herself."

"A married woman should renounce working if there is only a limited number of jobs and if her husband is able to provide the living for the family."
Evaluation of mother's paid employment (EMPLOY)

"A working mother can establish just as warm and secure a relationship with her child as a mother who does not work." (reverse coded)"

"A pre-school child is likely to suffer if his or her mother works and does not just take care of the home and family."

"For a child it is better if his or her mother works and does not just take care of the home and family." (reverse coded)"

Source: GGSS (1982-2016)

Using a confirmatory factor analysis, Lee et al. (2007) show that the six items can indeed be subdivided into the two subdimensions TGI and EMPLOY. Thus, two scales corresponding to the arithmetic mean of the individual items are computed. Reliability in terms of Cronbach's alpha ranges - depending on the wave - between .71 and .78 (TGI), and .56 and .72 (EMPLOY).

In order to indirectly model age effects, familial living arrangements and employment status are used as mediators (see section 4.2) and measured as follows:

- Familial living arrangements: Distinctions are drawn between (1) married persons with children (below 18 years of age, resident in the respondent's household), (2) unmarried persons with children, (3) married persons without children and (4) unmarried persons without children (cf. Cotter et al. 2011).

- Employment status: The employment status of the respondent and their partner or spouse is recorded according to four gradations: full-time employed, part-time employed, in education, and non-working (including small-scale employment and unemployment).

2 Reverse coded items are included in questionnaires to disrupt a response set where subjects respond favorably or unfavorably to all items. 
Information on a non-marital partner is not included in the GGSS 1982 wave. For this reason, for Western Germany, partner variables refer to the spouse only. Missing values not caused by structural reasons were handled via Full Information Maximum Likelihood (Acock 2005). Missing values for the dependent variables were not imputed. Instead, the scale values were computed here if the respondent had provided information pertaining to at least four of six items (Schafer/Graham 2002). The process of preparing and analysing the data is comprehensively documented in the attached syntax files.

\subsection{Analytical approach}

A key problem in age-period-cohort analysis is model identification - that is, the perfect linear relationship between age, survey time, and birth year (survey time - age = birth year). There are three main approaches for solving the identification problem:

- The first approach rests on the assumption that the dependent variable is only influenced by two of the three time dimensions (age, period and cohort). For example, Lee et al. (2007) assume that gender ideology does not change with increasing age. This is a strong theoretical assumption which might be incorrect.

- Second, the identifiability of the models can be guaranteed by equality constraints. Examples include the conventional Constrained Generalized Model (Mason 1973) or more recent approaches such as the Intrinsic Estimator (Yang/Land 2013). This approach is problematic because non-adequate restrictions can lead to biased estimators. At the same time, it mostly cannot be tested whether restrictions are adequate (Fienberg 2013).

- The third approach is based on equating the effect of one or more time dimensions with one substantive variable. It can be assumed, for example, that the cohort effect is proportional to the cohort size effect. The so-called mechanism-based approach (Winship/Harding 2008) the present study is based upon is a generalisation and extension of this idea.

The main idea of the analytical approach outlined in Figure 1 is to specify the mechanisms underlying age, period and cohort effects. Technically, the direct effects of the three time dimensions are replaced by indirect effects, for which age, period and cohort have an impact on mediator variables (employment status and familial living arrangement), which in turn influence the dependent variable (TGI and EMPLOY). In order to make the model identifiable, it is sufficient to estimate all relevant mechanisms for at least one of the three APC variables. Age seems to be appropriate for this context for two reasons: First, the age effect is weaker compared to the relatively strong period and cohort effects (see below). Second, age effects can be justified through the employment cycle and the family cycle (see Section 3).

Model specifications are based on the graph displayed in Figure 1. For the period and cohort, direct effects are estimated. The age effect, by contrast, is represented indirectly through mediators representing variables on employment and the family cycle. It must be considered that mediators can be so-called shared mechanisms. Full-time employment, for instance, is a state that does not only change subject to 
age but might also be affected by a period-specific shift. For example, the share of full-time employed women in Western Germany rose between 1982 and 2016 (see Table 2). The existence of shared mechanisms results in a specific requirement regarding appropriate mediators: A mediator variable can relate to a maximum of two dimensions (e.g. period and age, or cohort and age) to avoid another identification problem in the front part of the model (paths $b_{1}, b_{2}, b_{3}$ ). Hence, paths $b_{2}$ and $b_{3}$ are marked by dotted lines in Figure 1.

Covariance-based path models are estimated with MPlus. Familial living arrangement and employment status are measured by sets of dummy variables and therefore are nominal. Nevertheless, paths $b_{1}-b_{3}$ in Figure 1 are estimated using a linear link function. Based on Hellevik (2009) it is assumed that the use of linear regression in combination with binary outcomes has advantages with respect to estimation stability in path models. However, standard errors, which are by default (in OLS) calculated assuming normality for the outcome (conditional on covariates), will be potentially invalid. In order to avoid such bias, bootstrapping (Efron 2000) with 500 draws is used as estimation method in all models.

Fig. 1: Analytical approach

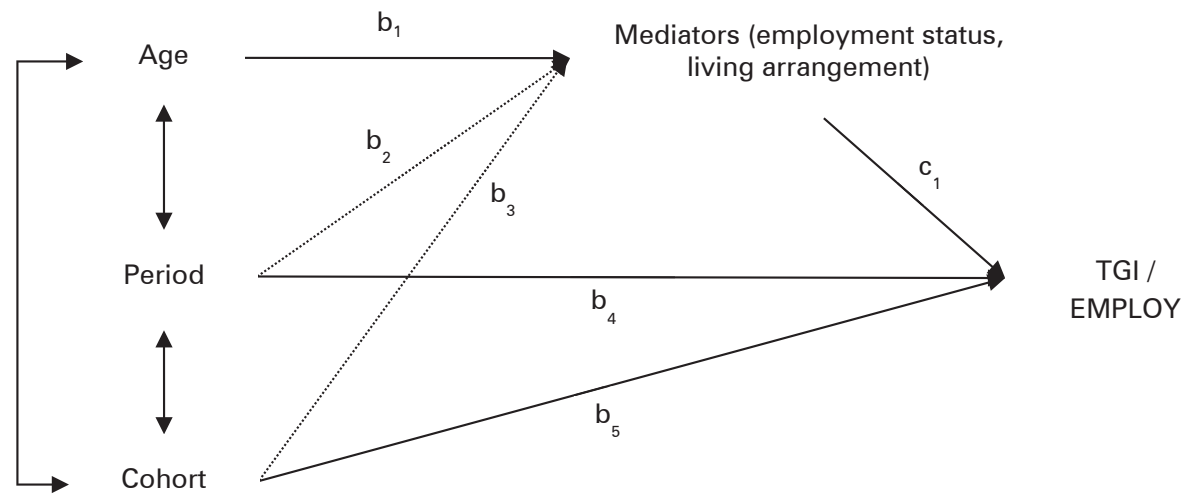

Source: own design

To illustrate the analytical approach based on a concrete example, the detailed output of the APC model for traditional gender ideology and West German women is presented in Table 2. ${ }^{3}$ The upper part of column i shows the direct effects of period and cohort on TGl, that is, the $b_{4}$ and $b_{5}$ paths in Figure 1. Two examples might illustrate the interpretation of these effects: First, the traditional gender ideology of West German women is 0.305 points higher for respondents interviewed in the year 1982 compared to the year 1991 (the reference category). Additionally, West German women born between 1892 and 1905 are much more traditional (by 0.713

3 Not shown in Table 2 are the estimated correlations between mediators, e.g. the correlations between employment status and familial living arrangements. 
Tab. 2: Mechanism-based age-period-cohort model (West German women, $\mathrm{N}=9445$ )

\begin{tabular}{|c|c|c|c|c|c|}
\hline $\begin{array}{l}\text { Independent } \\
\text { (paths in Fig. 1) }\end{array}$ & TGI & $\begin{array}{c}\text { Full-time } \\
\text { employment } \\
\text { ii }\end{array}$ & $\begin{array}{l}\text { Dependent } \\
\text { Part-time } \\
\text { employment } \\
\text { iii }\end{array}$ & $\begin{array}{c}\text { In education } \\
\text { iv }\end{array}$ & $\begin{array}{c}\text { Full-time } \\
\text { (spouse) } \\
\mathrm{v}\end{array}$ \\
\hline \multicolumn{6}{|l|}{$\operatorname{Age}\left(b_{1}\right)$} \\
\hline $18-28$ years & & ref. & ref. & ref. & ref. \\
\hline $29-46$ years & & -.086 & .178 & -.213 & .300 \\
\hline 47-61 years & & -.146 & .134 & -.225 & .048 \\
\hline $62+$ years & & -.405 & -.063 & -.251 & -.450 \\
\hline \multicolumn{6}{|l|}{ Period $\left(b_{2}, b_{4}\right)$} \\
\hline 1982 & .305 & -.006 & -.020 & .000 & \\
\hline 1991 & ref. & ref. & ref. & ref. & \\
\hline 1992 & .100 & -.017 & .016 & .001 & \\
\hline 1996 & .012 & .032 & .006 & -.007 & \\
\hline 2000 & .022 & .036 & .019 & .092 & \\
\hline 2004 & -.078 & .026 & .033 & -.001 & \\
\hline 2008 & -.127 & .033 & .042 & .017 & \\
\hline 2012 & -.233 & .048 & .087 & .022 & \\
\hline 2016 & -.307 & .088 & .110 & .019 & \\
\hline \multicolumn{6}{|l|}{ Cohort $\left(b_{3}, b_{5}\right)$} \\
\hline $1892-1905$ & .713 & & & & \\
\hline $1906-1910$ & .593 & & & & \\
\hline $1911-1915$ & .625 & & & & \\
\hline $1916-1920$ & .541 & & & & \\
\hline $1921-1925$ & .492 & & & & \\
\hline $1926-1930$ & .358 & & & & \\
\hline $1931-1935$ & .374 & & & & \\
\hline $1936-1940$ & .176 & & & & \\
\hline 1941-1945 & ref. & & & & \\
\hline $1946-1950$ & -.081 & & & & \\
\hline 1951-1955 & -.146 & & & & \\
\hline $1956-1960$ & -.235 & & & & \\
\hline $1961-1965$ & -.332 & & & & \\
\hline $1966-1970$ & -.296 & & & & \\
\hline $1971-1975$ & -.287 & & & & \\
\hline $1976-1980$ & -.257 & & & & \\
\hline 1981-1985 & -.236 & & & & \\
\hline 1986-1998 & -.182 & & & & \\
\hline \multicolumn{6}{|l|}{ Employment respondent $\left(c_{1}\right)$} \\
\hline Full-time & -.363 & & & & \\
\hline Part-time & -.293 & & & & \\
\hline In education & -.407 & & & & \\
\hline Non-working & ref. & & & & \\
\hline \multicolumn{6}{|l|}{ Employment spouse $\left(c_{1}\right)$} \\
\hline Full-time & -.030 & & & & \\
\hline Part-time & -.136 & & & & \\
\hline In education & -.134 & & & & \\
\hline Non-working & ref. & & & & \\
\hline \multicolumn{6}{|c|}{ Familial living arrangement (c1) } \\
\hline Unmarried, no children & -.145 & & & & \\
\hline Married without children & -.012 & & & & \\
\hline Unmarried with children & -148 & & & & \\
\hline Married with children & ref. & & & & \\
\hline Foreign citizen (control) & .402 & -.078 & -.052 & -.039 & -.057 \\
\hline$R^{2}$ & .32 & .11 & .09 & .15 & .33 \\
\hline
\end{tabular}


Tab. 2: Continuation

\begin{tabular}{|c|c|c|c|c|c|}
\hline $\begin{array}{l}\text { Independent } \\
\text { (paths in Fig. 1) }\end{array}$ & $\begin{array}{c}\text { Part-time } \\
\text { (spouse) } \\
\text { vi }\end{array}$ & $\begin{array}{c}\text { In education } \\
\text { (spouse) } \\
\text { vii }\end{array}$ & $\begin{array}{l}\text { Dependent } \\
\text { Not married, } \\
\text { no children } \\
\text { viii }\end{array}$ & $\begin{array}{l}\text { Married, } \\
\text { no children } \\
\text { ix }\end{array}$ & $\begin{array}{l}\text { Not married, } \\
\text { children } \\
x\end{array}$ \\
\hline \multicolumn{6}{|l|}{$\operatorname{Age}\left(b_{1}\right)$} \\
\hline $18-28$ years & ref. & ref. & ref. & ref. & ref. \\
\hline $29-46$ years & .005 & -.059 & -.381 & -.016 & .072 \\
\hline 47-61 years & .002 & -.065 & -.264 & -.401 & .016 \\
\hline $62+$ years & .000 & -.064 & -.094 & -.376 & -.014 \\
\hline \multicolumn{6}{|l|}{ Period $\left(b_{2}\right)$} \\
\hline 1982 & & -.002 & & & \\
\hline 1991 & & ref. & & & \\
\hline 1992 & & .004 & & & \\
\hline 1996 & & .007 & & & \\
\hline 2000 & & .012 & & & \\
\hline 2004 & & .004 & & & \\
\hline 2008 & & .012 & & & \\
\hline 2012 & & .013 & & & \\
\hline 2016 & & .027 & & & \\
\hline \multicolumn{6}{|l|}{ Cohort $\left(b_{3}\right)$} \\
\hline 1892-1905 & & & .515 & -.524 & -.012 \\
\hline $1906-1910$ & & & .487 & -.493 & -.010 \\
\hline $1911-1915$ & & & .423 & -.428 & -.011 \\
\hline $1916-1920$ & & & .326 & -.342 & -.003 \\
\hline $1921-1925$ & & & .258 & -.238 & -.024 \\
\hline $1926-1930$ & & & .137 & -.140 & .007 \\
\hline 1931-1935 & & & .080 & -.084 & -.006 \\
\hline $1936-1940$ & & & .013 & .016 & -.002 \\
\hline $1941-1945$ & & & ref. & ref. & ref. \\
\hline $1946-1950$ & & & .041 & -.029 & .002 \\
\hline $1951-1955$ & & & .036 & -.086 & -.010 \\
\hline $1956-1960$ & & & .027 & -.090 & .033 \\
\hline $1961-1965$ & & & .074 & -.123 & .027 \\
\hline $1966-1970$ & & & .096 & -.131 & .049 \\
\hline 1971-1975 & & & .151 & -.137 & .061 \\
\hline $1976-1980$ & & & .161 & -.117 & .037 \\
\hline $1981-1985$ & & & .209 & -.157 & .090 \\
\hline 1986-1998 & & & .340 & -.192 & .026 \\
\hline Foreign citizen (control) & -.057 & -.078 & -.078 & -.001 & -.009 \\
\hline$R^{2}$ & .002 & .05 & .22 & .22 & .04 \\
\hline
\end{tabular}

Source: GGSS (1982-2016, own calculations); coefficients: in bold, $p \leq .01$, in italics $\mathrm{p} \leq .05$.

points on a 4-point scale) than women of the birth cohort 1941-1945. Both effects are statistically significant at $p<.01$. The direct period effects and cohort effects on TGI and EMPLOY are discussed in more detail in the results sections (5.1 and 5.2).

As has been already discussed, no direct age effect is estimated. Instead, agespecific influences are represented indirectly by indicators covering employment status (of the respondent and the respondent's spouse) as well as familial living arrangement. Corresponding with the current state of research (Section 3), a more liberal gender ideology can be observed for the following groups: full-time employed women, part-time employed women and women who are currently enrolled in edu- 
cation. The reference category are non-working women. Furthermore, women who are unmarried and do not have children in their households, and women who live in a nonmarital cohabitation with children, are less traditional than women who are married and live with children. The corresponding effects are examples of $c_{1}$-paths in Figure 1. It is assumed that age influences are fully represented by the cumulative effects of employment status and familial living arrangement. Whether this assumption holds will be evaluated by model fit statistics which are discussed below.

In the remaining parts of the output in Table 2 (columns ii-x), the mediators, which indirectly cover age influences, are dependent variables. For example, the employment status of West German women is predicted by age ( $b_{1}-$ paths in Fig. 1), period $\left(b_{2}\right)$ and a dummy variable measuring foreign citizenship. To avoid the identification problem in this part of the model, cohort effects $\left(b_{3}\right)$ are assumed to be zero. Concerning age effects, it is confirmed that women in the youngest age group (which is the reference category) are more often employed full-time or enrolled in education than women in the older age groups are. In contrast, part-time employment is the typical employment status of women in the middle age groups (29-46 years and 47-61 years). Additionally, the period effects show that the participation of West German women in the labour market is growing (columns ii and iii) and that the share of persons who are currently enrolled in education is also rising over time (column iv for women and column vii for men). Because of the relative stability of West German men's employment behaviour over time, no period effects are estimated for men's full-time and part-time employment (columns $v$ and vi).

In the results section below (section 5.3), we will make indirect statements about age-specific changes of attitudes by computing specific indirect effects (Bollen 1987). The computation of these indirect effects can be reproduced using the output shown in Table 2. For example: West German women in the age group from 29-46 years are less likely to be employed full-time compared to women in the reference age between 18 and 28 years. The unstandardised effect "Age 29-46 (ref.: 18-28) $\rightarrow$ full-time employment" is $b=-0.086$. At the same time, women working full-time have a more liberal attitude compared to the reference category (non-working). The effect "full-time employment (ref.: non-working) $\rightarrow$ traditional gender ideology" is $b=-0.363$. Multiplying both partial effects $(-0.086 \times-0.363=0.031)$ results in the specific indirect effect.

In columns viii $-\mathrm{x}$ in Table 2, age and cohort effects on familial living arrangements are estimated. Period effects are assumed to be zero. It is intuitively plausible that the living arrangement "unmarried and not living with children" is most frequent for younger ages whereas the arrangement "married with children," which is the reference category here, is more typical in the oldest age group (62 years and older). Besides age effects, interesting cohort trends emerge. It can be observed that the number of unmarried couples with children tends to rise with the birth cohorts (column $\mathrm{x}$ ). This result reflects the declining importance of the "institution marriage" discussed in Section 3. Furthermore, West German women in older cohorts are significantly more often unmarried and childless than in successive cohorts (column viii). This is partly due to excess mortality in men in the Second World War (cf. Lengerer/Klein 2007). 
In sum, the model displayed in Table 2 makes several assumptions resulting in a distinct number of degrees of freedom (df):

- No direct age effects on the dependent variable are estimated, resulting in 3 degrees of freedom for the three age-specific dummy variables.

- For several covariates, it is assumed that age and period effects exist, but cohort effects do not: full-time employment and part-time employment as well as training phases of West German women and training phases of the woman's spouse. The effects of the corresponding cohort-specific dummy variables (17 in each case) are restricted to zero, resulting in 68 degrees of freedom $(4 \times 17)$.

- Concerning full-time employment and part-time employment of women's spouses, only age effects are specified. From this restriction, 50 degrees of freedom emerge (34 for cohort and 16 for period).

- With regard to familial living arrangements, which are measured using 3 dummy variables, age effects and cohort effects are estimated, and period effects are restricted to zero ( 24 degrees of freedom).

Thus, the APC model for West German women has $145(3+68+50+24)$ degrees of freedom in total.

A major advantage of the mechanism-based approach is the possibility to test the model restrictions with respect to their empirical fit using model fit indices. $\mathrm{X}^{2}$, RMSEA (Root Mean Square of Approximation; Browne and Cudeck 1992), CFI (Comparative Fit Index; Bentler 1990) and SRMR (Standardized Root Mean Square Residual; $\mathrm{Hu}$ and Bent/er, 1999) are used. Table 3 summarises the empirical fit of all models which are computed for the different groups of respondents and the two dimensions of gender role attitudes (TGI and EMPLOY). In general, there are only a few differences in the specification of the different models, which are mainly justified by the gender of the respective respondent. More specifically, whereas full-time employment and part-time employment of female respondents and female partners are predicted by period effects, the latter are set to zero for male respondents and male partners.

Table 3 shows fit statistics for each model. $X^{2}$ is a traditional measure for evaluating overall model fit and assesses "the magnitude of discrepancies between the sample and fitted covariances matrices" (Hu/Bentler 1999: 2). However, because $\mathrm{X}^{2}$ is a statistical significance test it is sensitive to sample size. This means that $\mathrm{X}^{2}$ nearly always rejects the model when large samples are used (cf. Hooper et al. 2008). Concerning further fit indices, the cut-off points for an acceptable model fit are at $<0.08$ (RSMEA), $>.90$ (CFI) and < 0.08 (SRMR; Hooper et al. 2008). Measured against these values, the fit is good for all eight models.

\section{$5 \quad$ Results}

Using the analytical approach demonstrated in the preceding section, the following sections are focused on the change of gender role attitudes depending on age, period and cohort. 
Tab. 3: Empirical fit of APC models

\begin{tabular}{lccrr}
\hline & \multicolumn{2}{c}{ West German } & \multicolumn{2}{c}{ East German } \\
& Women & Men & Women & Men \\
\hline X & \multicolumn{2}{c}{ Overall model fit (TGI) } & \\
Df & 1007.9 & 928.5 & 788.2 & 865.0 \\
RMSEA & 145 & 145 & 140 & 140 \\
CFI & 0.025 & 0.025 & 0.033 & 0.036 \\
SRMR & 0.971 & 0.968 & 0.952 & 0.938 \\
N & 0.009 & 0.009 & 0.012 & 0.012 \\
& 9445 & 8750 & 4265 & 3929 \\
X & & & & \\
Df & Overall model fit (EMPLOY) & & 875.3 \\
RMSEA & 1007.6 & 934.8 & 784.5 & 140 \\
CFI & 145 & 145 & 140 & 0.037 \\
SRMR & 0.025 & 0.025 & 0.033 & 0.935 \\
N & 0.969 & 0.966 & 0.951 & 0.012 \\
\hline
\end{tabular}

Source: GGSS (1982-2016, own calculations)

\subsection{Period effects}

In a first step, we investigate period effects (Fig. 2 and $3^{4}$ ) which are estimated while controlling indirectly for age and controlling directly for cohort. ${ }^{5}$ In Figure 2 , the development of the traditional gender ideology (TGI) with passing calendar time is displayed. First, a typical result is confirmed, in that men have more traditional attitudes than women. The development over time can be divided into three phases: The 1980s are, as documented by Braun et al. (1994), characterised by a rapid trend towards more liberal attitudes. The second phase (1991-2000), similarly to the development in the USA (Cotter et al. 2011), can be described as a sideways movement. Finally, in the third phase, the trends towards liberalisation speeds up again from 2000 onwards.

The development in the New Federal States can be subdivided into two phases. Following a trend of liberalisation between 1991 and 2004, a sideways trend is observable between 2004 and 2016. A potential explanation for this sideways trend is

4 The plotted 95 percent confidence intervals can be used for two-tailed hypothesis testing. For example, the gender role ideology of East German women in the year 2004 is significantly more egalitarian compared to the year 2000 because the corresponding confidence intervals do not overlap.

5 The level of the plotted lines in Figure 2 and 3 refers to a combination of the respective reference categories: German citizen, non-working, married with children, and cohort 1941-1945. 
Fig. 2: Period effects on traditional gender ideology (estimates with 95 percent confidence intervals)

Traditional gender ideology (fitted values)

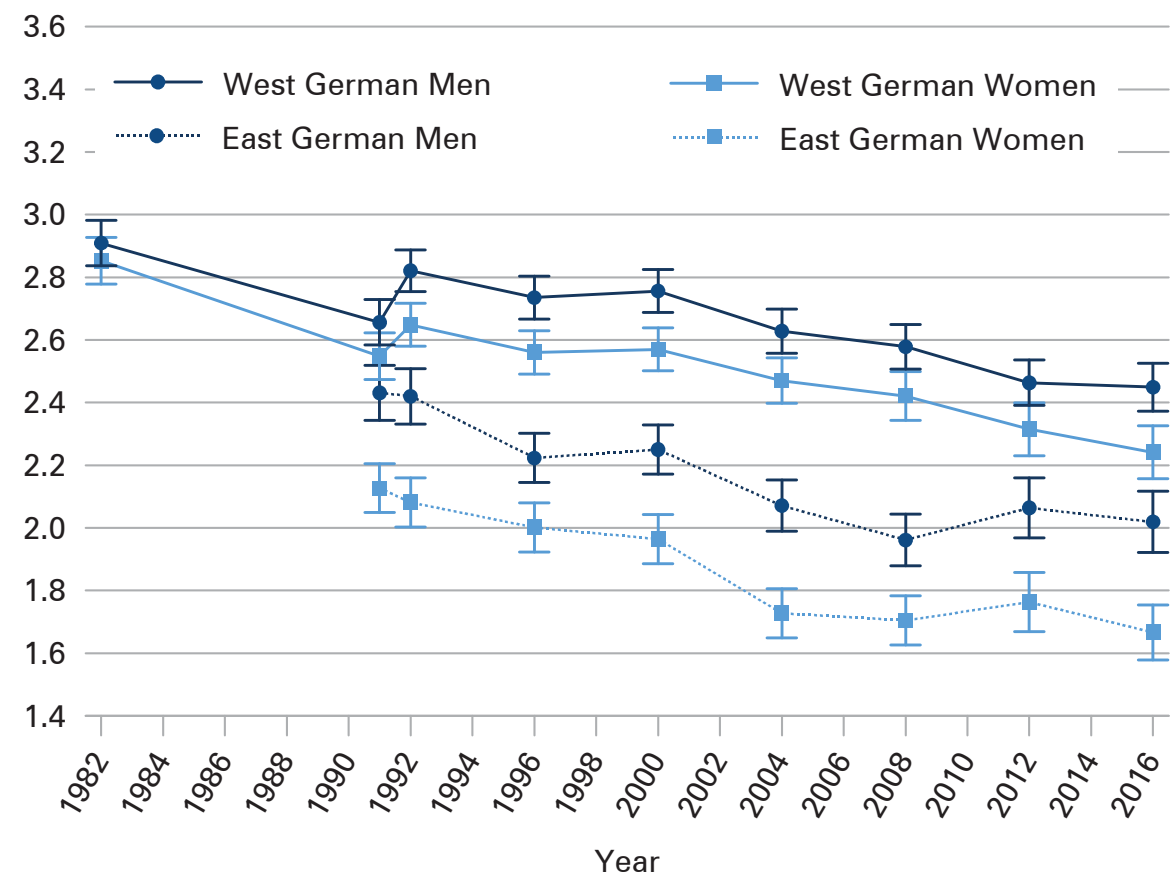

Source: GGSS (1982-2016, own calculations)

a "floor effect." The mean of East German women is 1.67 in 2016, which is already quite low on a 4-point scale. Because of the sideways trend in East Germany, the difference between Eastern and Western Germany, which had increased since 1991, decreased between 2008 and 2016.

Figure 3 shows how the negative evaluations of mothers' paid employment have changed over time. Higher values on the EMPLOY scale indicate that the respondent fears more negative consequences for small children if the mother is working. Compared with traditional gender ideology, some differences come to light. Regarding gender, West German men are much more sceptical of mothers' employment than West German women are. Furthermore, the difference between East and West is more pronounced because of a very positive evaluation of working mothers in East Germany. Furthermore, the Figure shows that the Western German trend towards more liberal attitudes, which had been stable for decades, came to a halt in recent waves between 2012 and 2016.

When interpreting the displayed trends, an important detail of the analytical approach must be kept in mind. Because the age and period dimensions share mechanisms (see Table 2), the displayed period effects are net of employment status. The corresponding specific indirect effects (Bollen 1987) are shown in Tables A1 
Fig. 3: Period effects on negative evaluations of mothers' paid employment (estimates with 95 percent confidence intervals)

EMPLOY (fitted values)

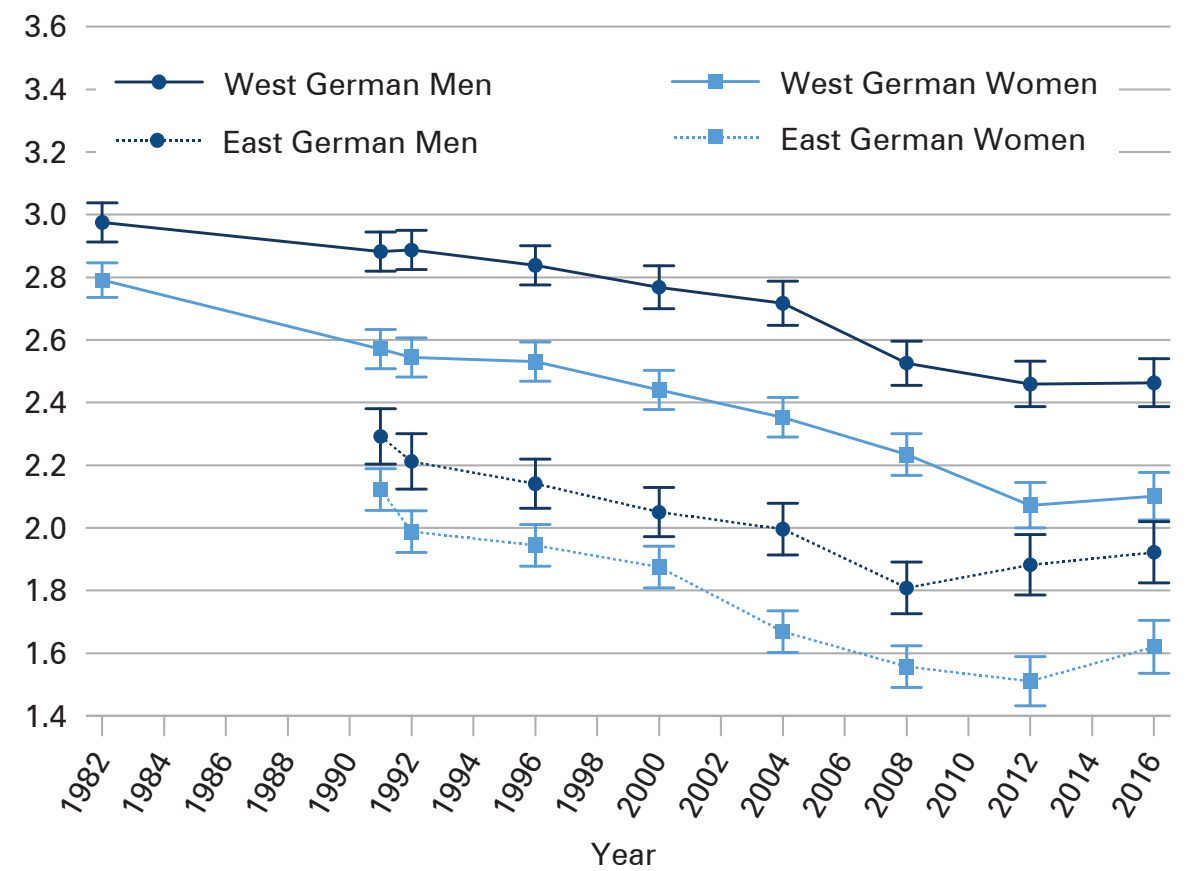

Source: GGSS (1982-2016, own calculations)

and $A 2^{6}$ in the Appendix. Accordingly, the negative period effects on TGI can be explained by two well-known mechanisms: the increasing extension of educational training phases and the increasing employment of women, especially in Western Germany. Using specific indirect effects, it can be computed to which extent the net effects displayed in Figures 2 and 3 are already explained (reduced) by controlling for employment status. The multivariate reduction is 11.7 percent for West German women and TGI. In all other groups and for the dimension EMPLOY multivariate effect reduction is smaller and does not exceed 8 percent in any case.

6 In order to calculate the specific indirect effects in Tables A1 and A2, calendar time is modelled using a linear term instead of dummy variables. Example: The indirect effect "Year $\rightarrow$ full-time employed $\rightarrow$ TGI" is negative $(b=-0.0007)$. This is because, on the one hand, full-time employment of West German women has increased over calendar time $(b=0.002)$ and, on the other hand, full-time employed women hold more egalitarian attitudes than non-working women $(b=-0.359)$. The specific indirect effect equals $0.002 \times-0.359=-0.0007$. 


\subsection{Cohort effects}

Next, we look at cohort effects. In Figure 4, the development of traditional gender ideology over 18 birth cohorts is displayed. In Western Germany, a strong trend towards more egalitarian attitudes is apparent. It starts with cohort 1931-1935 for men and with cohort 1936-1940 for women. However, beginning with cohorts 1956-1960 (men) and 1966-1970 (women), the liberalisation trend ends and turns into a sideways trend. Because the cohort effect for TGI in Western Germany can be described as u-shaped, an additional model is specified in which the cohort-specific dummy variables were replaced by cohort and cohort squared. Cohort squared has a positive effect for men and women which is statistically significant with $p<.01$. Thus, the u-shaped pattern is confirmed by this specification. At this point, the results markedly differ from earlier studies which have reported that every younger cohort is more liberal than its predecessor.

Fig. 4: $\quad$ Cohort effects on traditional gender ideology (estimates with 95 percent confidence intervals)

Traditional gender ideology (fitted values)

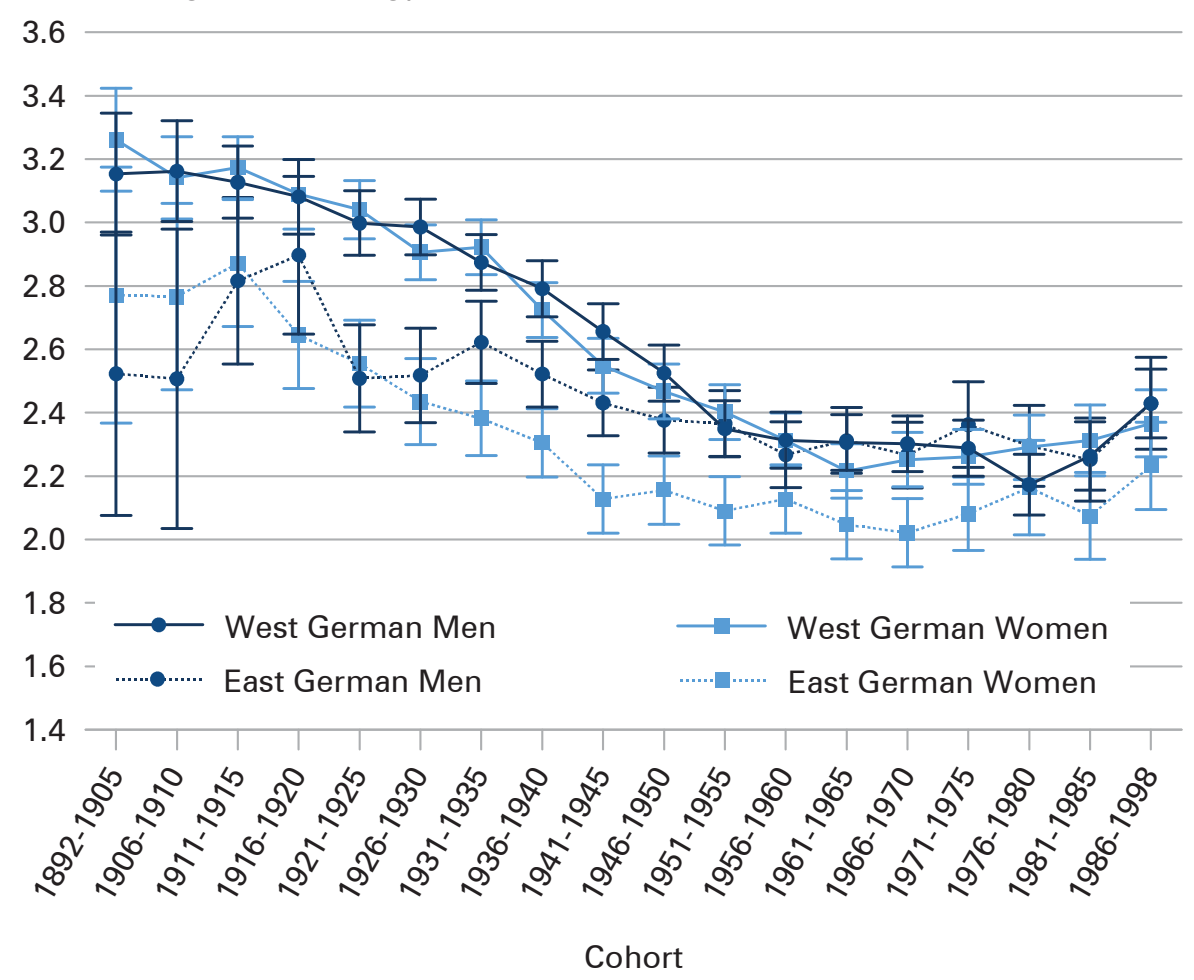

Source: GGSS (1982-2016, own calculations) 
A u-shaped pattern is also observable in Eastern Germany. The trend towards more liberal attitudes mainly spans across cohorts which were socialised prior to German partition (i.e. 1892-1930) or in the early GDR (1934-1945). Starting between birth years 1951-1960, a sideways trend is observable for East German men and East German women which still holds in post-reunification cohorts from 1975 onwards.

Furthermore, it is apparent that cohort effects are much stronger in Western Germany because West German cohorts, starting from a rather high baseline level, converge to the East German level. Additionally, gender differences are greater in Eastern Germany because the cohort effect is stronger for East German women than for East German men.

With respect to the assessment of mothers' employment (Fig. 5), cohort effects are weaker. For West German women, a u-shaped pattern is observable with the most egalitarian cohorts between 1941 and 1970. For West German men, the cohort effect is linear negative.

Furthermore, if the development in Eastern Germany is compared between the sexes, interesting results emerge. In the case of East German men, no systematic

Fig. 5: Cohort effects on negative evaluation of mothers' paid employment (estimates with 95 percent confidence intervals)

EMPLOY (fitted values)

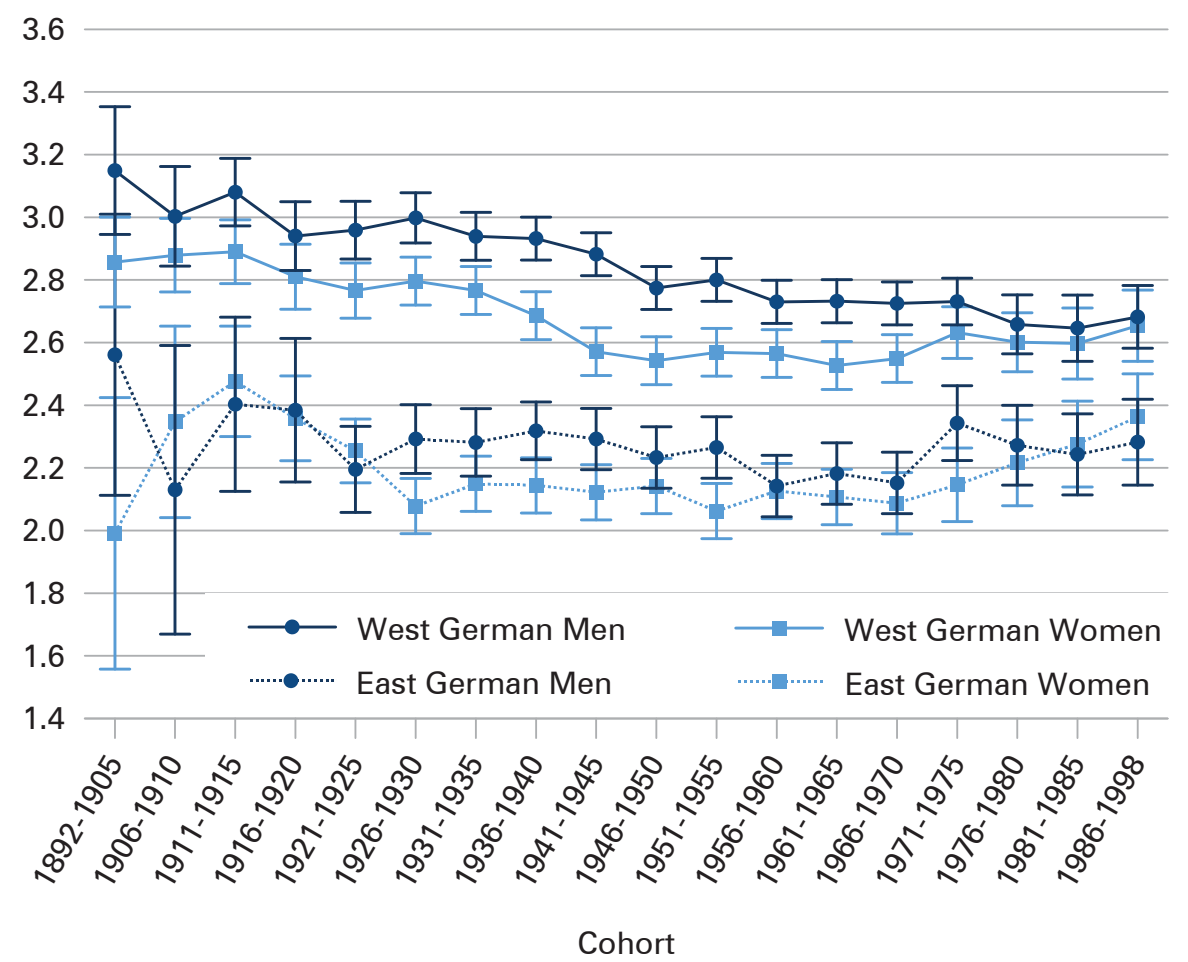

Source: GGSS (1982-2016, own calculations) 
cohort effect exists. However, for East German women, the cohort effect clearly follows a u-shaped pattern. Mothers' paid employment is - with the exception of the oldest cohort - most positively evaluated between birth years 1926-1970, i.e. from those cohorts who were socialised in the GDR. Women in post-reunification cohorts (1971-1975 onwards) are still more sceptical concerning mothers' employment, however. ${ }^{7}$

Once again, because of shared mechanisms, it must be mentioned that the cohort effects displayed in Figures 4 and 5 are net of a substantial covariate; familial living arrangement, in this case. The corresponding specific indirect effects are given in Tables $\mathrm{A} 1$ and $\mathrm{A} 2$ in the Appendix. ${ }^{8}$

\subsection{Age effects}

Finally, to complete the APC analyses, age effects are assessed based on the specific indirect effects, which are displayed in Tables 4 and 5 (see also Section 4.2 for a computational example). The results show that TGI increases with West German and East German women over the course of life, as they are less likely to work fulltime with increasing age and, moreover, are less probable to be in training phases. This process begins later with East German women than with West German women. Part-time employment is only of importance among West German women: Women working part-time have more liberal attitudes than non-working women. At the same time, West German women in the middle age groups (29-46 years and 47-61 years) work part-time more often than in the youngest and oldest age groups. For the age group of 29-61 years, part-time employment therefore results in a liberalisation in gender role ideology.

As West and East German men are less likely to be affected by family-related career breaks, only the transition to retirement leads to a turn towards more traditional TGI values from age 62 onwards (compared to the 18-28 reference group). For the middle age range (29-46 years), the frequent full-time employment of men has a liberalising effect. Moreover, West German men are particularly affected by partner effects (Kalmijn 2005). Thus, most notably, part-time employment of West German female spouses in the age group 29-62 correlates with a more liberal TGI of the West German male spouse. More importantly, the training phase of the partner has a liberalising effect on the TGI in all age groups, beyond own training phases (cf. Bryant 2003).

7 In a model not shown, the effect of the birth year ${ }^{2}$ is significant with $p<.001$, which confirms the u-shaped pattern of the cohort effect.

8 The analytical approach chosen here is to select three birth cohorts (1926-1930, 1946-1950 and 1976-1980) which are compared to the reference cohort (1906-1910). Most importantly, indirect effects show that respondents from older West German birth cohorts (1906-1910) were on the one hand more frequently unmarried and childless than respondents from younger cohorts. This can be partly explained by the excess mortality of men in the Second World War (Lengerer) Klein 2007). On the other hand, unmarried and childless persons hold less traditional attitudes than respondents who are married and have children. Accordingly, the respective indirect effects in Tables $A 1$ and $A 2$ are positive. 
Tab. 4: Decomposition of age effects (traditional gender ideology, unstandardised specific indirect effects)

\begin{tabular}{|c|c|c|c|c|}
\hline \multirow[t]{2}{*}{ Indirect effect (mechanism) } & \multicolumn{2}{|c|}{ West German } & \multicolumn{2}{|c|}{ East German } \\
\hline & Women & Men & Women & Men \\
\hline \multicolumn{5}{|l|}{ Employment status } \\
\hline Age $29-46 \rightarrow$ full-time employed $\rightarrow$ TGI & $.031^{* *}$ & $-.022 * *$ & $-.019 * *$ & $-.021 * *$ \\
\hline Age $47-61 \rightarrow$ full-time employed $\rightarrow$ TGI & $.052^{* *}$ & $-.013^{* *}$ & $.021 * *$ & -.003 \\
\hline Age $62+\rightarrow$ full-time employed $\rightarrow$ TGI & $.145^{* *}$ & $.039 * *$ & $.114^{* *}$ & $.062 * *$ \\
\hline Age $29-46 \rightarrow$ full-time partner $\rightarrow$ TGI & $-.010+$ & $-.012^{* *}$ & .005 & $-.056 * *$ \\
\hline Age $47-61 \rightarrow$ full-time partner $\rightarrow$ TGI & -.002 & -.005 & -.002 & $-.046^{* *}$ \\
\hline Age $62+\rightarrow$ full-time partner $\rightarrow$ TGI & $.016+$ & $.039 * *$ & -.013 & $.026^{* *}$ \\
\hline Age $29-46 \rightarrow$ part-time employed $\rightarrow$ TGI & $-.052^{* *}$ & .000 & -.002 & -.000 \\
\hline Age $47-61 \rightarrow$ part-time employed $\rightarrow$ TGI & $-.043^{* *}$ & .000 & -.001 & -.000 \\
\hline Age $62+\rightarrow$ part-time employed $\rightarrow$ TGI & $.019 * *$ & .000 & .003 & .001 \\
\hline Age $29-46 \rightarrow$ part-time partner $\rightarrow$ TGI & -.001 & $-.036 * *$ & -.000 & -.004 \\
\hline Age $47-61 \rightarrow$ part-time partner $\rightarrow$ TGI & .000 & $-.040 * *$ & -.000 & -.004 \\
\hline Age $62+\rightarrow$ part-time partner $\rightarrow$ TGI & -.000 & $-.003^{* *}$ & .000 & -.000 \\
\hline Age $29-46 \rightarrow$ in education $\rightarrow \mathrm{TGI}$ & $.083^{* *}$ & $.056^{* *}$ & $.028^{* *}$ & $.043^{* *}$ \\
\hline Age $47-61 \rightarrow$ in education $\rightarrow$ TGI & $.088^{* *}$ & $.059 * *$ & $.034^{* *}$ & $.044^{* *}$ \\
\hline Age $62+\rightarrow$ in education $\rightarrow$ TGI & $.098^{* *}$ & $.066^{* *}$ & $.041^{* *}$ & $.048^{* *}$ \\
\hline Age $29-46 \rightarrow$ partner in education $\rightarrow$ TGI & $.008^{*}$ & $.023^{* *}$ & .007 & $.030 * *$ \\
\hline Age $47-61 \rightarrow$ partner in education $\rightarrow$ TGI & $.009 *$ & $.027^{* *}$ & .008 & $.032^{* *}$ \\
\hline Age $62+\rightarrow$ partner in education $\rightarrow \mathrm{TGI}$ & $.009 *$ & $.028^{* *}$ & .008 & $.033^{* *}$ \\
\hline \multicolumn{5}{|l|}{ Familial living arrangement } \\
\hline Age $29-46 \rightarrow$ not married, children $\rightarrow$ TGI & $-.011 * *$ & $-.004+$ & -.004 & -.001 \\
\hline Age $47-61 \rightarrow$ not married, children $\rightarrow$ TGI & -.003 & -.003 & .001 & -.000 \\
\hline Age $62+\rightarrow$ not married, children $\rightarrow$ TGI & .002 & -.002 & .001 & -.000 \\
\hline Age $29-46 \rightarrow$ not married, no child $\rightarrow$ TGI & $.058^{* *}$ & $.060 * *$ & .004 & -.004 \\
\hline Age $47-61 \rightarrow$ not married, no child $\rightarrow$ TGI & $.040^{* *}$ & $.062^{* *}$ & .002 & -.003 \\
\hline Age $62+\rightarrow$ not married, no child $\rightarrow$ TGI & $.014^{* *}$ & $.053^{* *}$ & -.000 & -.002 \\
\hline Age $29-46 \rightarrow$ married, no child $\rightarrow$ TGI & .000 & -.001 & .002 & -.003 \\
\hline Age $47-61 \rightarrow$ married, no child $\rightarrow$ TGI & -.006 & -.011 & .022 & -.019 \\
\hline Age $62+\rightarrow$ married, no child $\rightarrow$ TGI & -.006 & -.016 & .018 & -.022 \\
\hline
\end{tabular}

** $\mathrm{p} \leq .01 ;{ }^{*} \mathrm{p} \leq .05 ;+\mathrm{p} \leq .10$

References: Age 18-28, non-working, married with children

Source: GGSS (1982-2016, own calculations)

The intervening effects of the familial living arrangement (lower part of Table 4) tend to be rather weak and can only be observed for West Germany. For example, West German women in the age group 29-46 have more liberal attitudes, as they live in an unmarried household with children more often than younger and older women do. Here, married women with children represent the reference category. The TGI of unmarried persons without children is also rather liberal. The loss of 
importance of this living arrangement over the course of life can partly explain why West German men and women become more traditional with increasing age.

A similar decomposition for the EMPLOY dimension is shown in Table 5. Compared with TGI, results of EMPLOY show a similar structure although being weaker than for TGI.

Tab. 5: Decomposition of age effects (negative evaluation of mother's gainful employment, unstandardised specific indirect effects)

\begin{tabular}{|c|c|c|c|c|}
\hline \multirow[t]{2}{*}{ Indirect effect (mechanism) } & \multicolumn{2}{|c|}{ West German } & \multicolumn{2}{|c|}{ East German } \\
\hline & Women & Men & Women & Men \\
\hline \multicolumn{5}{|l|}{ Employment status } \\
\hline Age 29-46 $\rightarrow$ full-time employed $\rightarrow$ E. & $.023^{* *}$ & -.003 & $-.008^{*}$ & .002 \\
\hline Age 47-61 $\rightarrow$ full-time employed $\rightarrow$ E. & $.038^{* *}$ & -.002 & $.009^{*}$ & .000 \\
\hline Age $62+\rightarrow$ full-time employed $\rightarrow E$ & $.107^{* *}$ & .005 & $.048 * *$ & -.006 \\
\hline Age $29-46 \rightarrow$ full-time partner $\rightarrow$ E. & -.001 & $-.011 * *$ & .001 & $-.028 * *$ \\
\hline Age $47-61 \rightarrow$ full-time partner $\rightarrow$ E. & -.002 & -.005 & -.000 & $-.023^{* *}$ \\
\hline Age $62+\rightarrow$ full-time partner $\rightarrow$ EMPLOY & .012 & $.038 * *$ & -.002 & $.013^{* *}$ \\
\hline Age $29-46 \rightarrow$ part-time employed $\rightarrow$ E. & $-.053^{* *}$ & .000 & .002 & .001 \\
\hline Age 47-61 $\rightarrow$ part-time employed $\rightarrow \mathrm{E}$. & $-.040 * *$ & .000 & .001 & .001 \\
\hline Age $62+\rightarrow$ part-time employed $\rightarrow \mathrm{E}$ & $.019 * *$ & .001 & -.003 & -.002 \\
\hline Age $29-46 \rightarrow$ part-time partner $\rightarrow$ E. & .000 & $-.033^{* *}$ & .002 & .004 \\
\hline Age $47-61 \rightarrow$ part-time partner $\rightarrow \mathrm{E}$ & -.000 & $-.036 * *$ & .001 & .005 \\
\hline Age $62+\rightarrow$ part-time partner $\rightarrow$ EMPLOY & -.000 & $-.003 * *$ & -.000 & .000 \\
\hline Age $29-46 \rightarrow$ in education $\rightarrow$ EMPLOY & $.053^{* *}$ & .006 & $.019 * *$ & -.005 \\
\hline Age $47-61 \rightarrow$ in education $\rightarrow$ EMPLOY & $.062^{* *}$ & .007 & $.022^{* *}$ & -.005 \\
\hline Age $62+\rightarrow$ in education $\rightarrow$ EMPLOY & $.064 * *$ & .008 & $.027^{* *}$ & -.005 \\
\hline Age $29-46 \rightarrow$ partner in education $\rightarrow E$ & .004 & $.010^{* *}$ & .003 & .006 \\
\hline Age $47-61 \rightarrow$ partner in education $\rightarrow \mathrm{E}$ & .004 & $.012^{* *}$ & .003 & .007 \\
\hline Age $62+\rightarrow$ partner in education $\rightarrow \mathrm{E}$ & .004 & $.013^{* *}$ & .003 & .007 \\
\hline \multicolumn{5}{|l|}{ Familial living arrangement } \\
\hline Age $29-46 \rightarrow$ not married, children $\rightarrow$ E. & $-.014^{* *}$ & $-.006^{*}$ & -.007 & -.006 \\
\hline Age $47-61 \rightarrow$ not married, children $\rightarrow E$ & -.003 & $-.004^{*}$ & .001 & -.002 \\
\hline Age $62+\rightarrow$ not married, children $\rightarrow E$ & .003 & $-.003+$ & .001 & -.001 \\
\hline Age $29-46 \rightarrow$ not married, no child $\rightarrow E$ & .005 & $.042^{* *}$ & -.008 & .004 \\
\hline Age 47-61 $\rightarrow$ not married, no child $\rightarrow$ E. & .004 & $.043^{* *}$ & -.003 & .003 \\
\hline Age $62+\rightarrow$ not married, no child $\rightarrow$ E. & .001 & $.037^{* *}$ & .001 & .002 \\
\hline Age 29-46 $\rightarrow$ married, no child $\rightarrow$ E. & -.000 & .000 & -.000 & $-.004+$ \\
\hline Age 47-61 $\rightarrow$ married, no child $\rightarrow$ E. & .011 & .004 & -.005 & $-.029+$ \\
\hline Age $62+\rightarrow$ married, no child $\rightarrow$ EMPLOY & .010 & .005 & -.004 & $-.033+$ \\
\hline
\end{tabular}

${ }^{*} \mathrm{p} \leq .01 ;{ }^{*} \mathrm{p} \leq .05 ;+\mathrm{p} \leq .10$

References: Age 18-28, non-working, married with children

Source: GGSS (1982-2016, own calculations) 


\section{Conclusion}

The aim of the present paper was to decompose the change in gender role attitudes, i.e. traditional gender ideology and assesments of mothers' paid employment, using a full-fledged, elaborated APC approach as developed by Winship and Harding (2008). A first important result of the analyses is that, in nearly all groups studied, all three time dimensions - age, period, and cohort - have an independent effect. The decomposition of age effects shows that gender attitudes within the lifecourse change according to status passages such as starting education, entering the labour market, or starting a family. These age effects are significant net of period and cohort effects. Thus, the validity of earlier studies which have ignored age is questionable (Braun et al. 1994; Lee et al. 2007). Additionally, the present results are at odds with Baier's study (2014) which does not identify an independent age effect.

By extending the analytical approach to a full APC model, new insights concerning the actual shape of APC effects come to light. This is especially true for cohort effects. Previous studies reported that gender ideology is becoming increasingly egalitarian from cohort to cohort in Germany. The findings presented here slightly contradict this assumption: A relatively pronounced trend towards more egalitarian attitudes is, indeed, initially seen specific to Western Germany; this sets in roughly from the 1936-1940 cohort onwards. After a certain time lag in relation to the USA, where no further liberalisation is evident from the 1952 cohort onwards, the trend towards increasingly liberal gender roles nevertheless turns into a sideways trend from the 1956-1960 (men) and 1966-1970 (women) cohorts onwards. This development becomes plausible if it is, at least in part, seen as a historical reflection of the various phases of the New Women's Movement. This likely contributed, primarily in the 1970s, to a liberalisation of gender role orientations, forfeiting its pervasive socialisation influence to some extent once again in the decades that followed. With the data at hand, it cannot be evaluated to what extent the debate on sexism, e.g. the \#MeToo movement from October 2017 onwards, will lead to a reinforcement of the cohort-specific liberalisation trend. This is an interesting issue for future research.

In Eastern Germany, cohort effects generally tend to be weaker than in Western Germany. Again, the liberalisation trend comes to a halt in some groups and changes into a sideways trend. For example, East German women from the postreunification cohort 1971-1975 increasingly see the employment of women in the context of young children more sceptically. The development of cohort effects in the new federal states appears to be a historical reflection of the consolidation and dissolution of the GDR. Those in the Eastern German 1940-1960 cohorts are considered to have been most emphatically shaped by a more egalitarian climate of opinion, which was characterised by socialist ideology and the labour market and family policies of the GDR. By contrast, the structural changes in the course of reunification appear to have contributed to a slight weakening of liberalising socialisation influences in younger cohorts.

Concerning period effects, on the one hand, the present results confirm earlier research. In all groups a trend towards more liberal attitudes can be observed 
with the passing of calendar time. On the other hand, there are some hints that the period-specific trend turns into a sideways trend as well. This is especially true for Eastern Germany since the year 2004. However, potential "floor effects" have to be taken into account, because the vast majority of East German respondents disagrees with statements which express traditional attitudes in recent years. Hence, the potential of the GGSS items to measure liberalisation tends to be exhausted. Against this backdrop, it is understandable why new items have been tested since the 2012 GGSS wave.

Finally, attention should be drawn to restrictions largely to be found in the type of trend data. In some of the contexts discussed here (e.g., women's employment, familial living arrangements), the direction of causation is unclear. Does parenthood, for instance, result in traditional gender roles, or are those with traditional attitudes more likely to be parents? Since this study is not based upon panel data, the causal direction can be clarified only to a limited extent. Particularly for determining age and life course effects, panel data are advantageous compared to trend data, as they make repeated observations of the same person before and after central biographical transitions.

From a methodological point of view, it has become clear that the mechanismbased approach has high requirements for both theory and data because of the necessity to specify all relevant mechanisms for at least one of the APC dimensions. However, a major advantage of the approach is also confirmed: while model restrictions in alternative APC models largely remain unproven, it is possible to test the empirical model fit in the framework of the mechanism-based model. Accordingly, under specific conditions, this approach seems to be one of the most promising ways of dealing with the identification problem in the field of future APC analyses.

\section{References}

Acock, Alan C. 2005: Working with Missing Values. In: Journal of Marriage and Family 67: 1012-1028 [doi: 10.1111/j.1741-3737.2005.00191.x].

Amato, Paul R.; Booth, Alan 1995: Changes in Gender Role Attitudes and Perceived Marital Quality. In: American Sociological Review 60,1: 58-66 [doi: 10.2307/2096345].

Arránz Becker, Oliver; Lois, Daniel; Nauck, Bernhard 2010: Differences in Fertility Patterns between East and West German Women. Disentangling the Roles of Culturel Background and of the Transformation Process. In: Comparative Population Studies Zeitschrift für Bevölkerungswissenschaft 35,1: 7-34 [doi: 10.4232/10.CPoS-2010-02en].

Baier, Dirk 2014: Von der "Krise der Jungen" zum “Triumph der Mädchen": Entwicklung der Geschlechterrollenorientierung in Deutschland. In: Mößle, Thomas; Pfeiffer, Christian; Baier, Dirk (Eds.): Die Krise der Jungen: Phänomenbeschreibung und Erklärungsansätze Baden-Baden: Nomos: 257-269.

Beck, Vanessa 2003: Female Unemployment in the East: Or, How to Stay in the Labuor Market. In: Kolinsky, Eva; Nickel, Hildegard M. (Eds.): Reinventing Gender: Women in Eastern Germany since Reunification. London: Frank Cass: 172-189. 
Becker, Rolf 2006: Dauerhafte Bildungsungleichheiten als unerwartete Folge der Bildungsexpansion? In: Hadjar, Andreas; Becker, Rolf (Eds.): Die Bildungsexpansion. Erwartete und unerwartete Folgen. Wiesbaden: VS-Verlag: 27-62 [doi: 10.1007/9783-531-90325-5_2].

Bentler, Peter M. 1990: Comparative Fit Indexes in Structural Models. In: Psychological Bulletin 107: 238-246 [doi: 10.1037/0033-2909.107.2.238].

Bollen, Kenneth A. 1987: Total, Direct, and Indirect Effects in Structural Equation Models. In: Sociological Methodology 17: 37-69 [doi: 10.2307/271028].

Bolzendahl, Catherine; Myers, Danie/ J. 2004: Feminist Attitudes and Support for Gender Equality: Opinion Change in Women and Men, 1974-1998. In: Social Forces 83: 759-789.

Braun, Michael; Scott, Jacqueline; Alwin, Duane F. 1994: Economic Necessity or SelfActualization? Attitudes toward Womens Labor-Force Participation in East and WestGermany In: European Sociological Review 10: 29-47 [doi: 10.1093/oxfordjournals.esr. a036314].

Braun, Michael; Alwin, Duane F.; Scott, Jacqueline 1994: Wandel der Einstellungen zur Rolle der Frau in Deutschland und den Vereinigten Staaten. In: Braun, Michael; Mohler, Peter (Eds.): Blickpunkt Gesellschaft 3 - Einstellungen und Verhalten der Bundesbürger. Opladen: Westdeutscher Verlag: 151-173 [doi: 10.1007/978-3-322-92480-3_7].

Brewster, Karin L.; Padavic, Irene 2000: Change in Gender-Ideology, 1977-1996: The Contributions of Intracohort Change and Population Turnover. In: Journal of Marriage and Family 62,2: 477-487 [doi: 10.1111/j.1741-3737.2000.00477.x].

Brooks, Clem; Bolzendahl, Catherine 2004: The Transformation of US Gender Role Attitudes: Cohort Replacement, Social-Structural Change, and Ideological Learning. In: Social Science Research 33,1: 106-133 [doi: 10.1016/S0049-089X(03)00041-3].

Browne, Michael W.; Cudeck, Robert 1992: Alternative Ways of Assessing Model Fit. In: Sociological Methods \& Research 21,2: 230-258 [doi: 10.1177/0049124192021002005].

Bryant, Alyssa N. 2003: Changes in Attitudes Toward Women's Roles: Predicting Gender-Role Traditionalism Among College Students. In: Sex Roles 48: 131-142 [doi: 10.1023/A:1022451205292].

Bujard, Martin; Sulak, Harun 2016: Mehr Kinderlose oder weniger Kinderreiche? In: Kölner Zeitschrift für Soziologie und Sozialpsychologie 68,3: 487-514 [doi: 10.1007/ s11577-016-0373-6].

Cotter, David ; Hermsen, Joan M.; Vanneman, Reeve 2011: The End of the Gender Revolution? Gender Role Attitudes from 1977 to 2008. In: American Journal of Sociology 117,1: 259-289 [doi: 10.1086/658853].

Crouter, Ann C. et al. 2007: Development of Gender Attitude Traditionality Across Middle Childhood and Adolescence. In: Child Development 78: 911-926.

Davis, Shannon N. 2007: Gender Ideology Construction from Adolescence to Young Adulthood. In: Social Science Research 36,3: 1021-1041 [doi: 10.1016/j.ssresearch.2006.08.001].

Efron, Bradley 2000: The Bootstrap and Modern Statistics. In: Journal of the American Statistical Association 95,452: 1293-1296 [doi: 10.1080/01621459.2000.10474333].

Fienberg, Stephen E. 2013: Cohort Analysis' Unholy Quest: A Discussion. In: Demography 50,6: 1981-1984 [doi: 10.1007/s13524-013-0251-z].

GESIS 2016: German General Social Survey (ALLBUS) - Cumulation 1980-2014. GESIS Data Archiv. ZA4584 Data file version 1.0.0. Cologne: GESIS. 
Greenstein, Theodore N. 1996: Husband's Participation in Domestic Labor: Interactive Effects of Wives' and Husbands' Gender Ideologies. In: Journal of Marriage and the Family 58: 585-595 [doi: 10.2307/353719].

Hellevik, Ottar 2009: Linear versus Logistic Regression when the Dependent Variable is a Dichotomy. In: Quality \& Quantity 43,1: 59-74 [doi: 10.1007/s11135-007-9077-3].

Holst, Elke; Wieber, Anna 2014: Bei der Erwerbstätigkeit der Frauen liegt Ostdeutschland vorn. In: DIW-Wochenbericht 40: 967-976.

Hooper, Daire; Coughlan, Joseph; Mullen, Michael R. 2008: Structural Equation Modeling: Guidelines for Determining Model Fit. In: The Electronic Journal of Business Research Methods 6,1: 53-60.

Hu, Li-Tze; Bentler, Peter M. 1999: Cutoff Criteria for Fit Indexes in Covariance Structure Analysis: Conventional Criteria versus New Alternatives. In: Structural Equation Modeling 6,1: 1-55 [doi: 10.1080/10705519909540118].

Kalmijn, Matthijs 2005: Attitude Alignment in Marriage and Cohabitation: The Case of Sex-Role Attitudes. In: Personal Relationships 12,4: 521-535 [doi: 10.1111/j.14756811.2005.00129.x].

Karl, Michaela 2011: Die Geschichte der Frauenbewegung. Stuttgart: Reclam.

Katz-Wise, Sabra L.; Priess, Heather A.; Hyde, Janet S. 2010: Gender-Role Attitudes and Behavior Across the Transition to Parenthood. In: Developmental Psychology 46,1: 18-28 [doi: 10.1037/a0017820].

Kaufman, Gayle 2000: Do Gender Role Attitudes Matter? Family Formation and Dissolution Among Traditional and Egalitarian Men and Women. In: Journal of Family Issues 21,1: 128-144 [doi: 10.1177/019251300021001006].

Krampen, Günter 1979: Eine Skala zur Messung der normativen Geschlechtsrollen-Orientierung (GRO-Skala). In: Zeitschrift für Soziologie 8,3: 254-266 [doi: 10.1515/ zfsoz-1979-0304].

Kreyenfeld, Michaela 2000: Changes in the Timing of First Birth in East Germany after Re-unification. In: Schmollers Jahrbuch. Zeitschrift für Wirtschafts- und Sozialwissenschaften 120,2: 169-186.

Lee, Kristen S.; A/win, Duane F.; Tufis, Paula A. 2007: Beliefs about Woman's Labour in the Reunified Germany, 1991-2004. In: European Sociological Review 23,4: 487-503 [doi: 10.1093/esr/jcm015].

Lengerer, Andrea; Klein, Thomas 2007: Der langfristige Wandel partnerschaftlicher Lebensformen im Spiegel des Mikrozensus. In: Wirtschaft und Statistik 4/2017: 433-447.

Lois, Danie/ 2011: Church membership and church attendance across time - A trend analysis considering differences between East and West Germany. In: Comparative Population Studies - Zeitschrift für Bevölkerungswissenschaft 36: 161-192 [doi: 10.4232/10.CPoS-2011-04en].

Mason, Karen Oppenheim; Lu, Yu-Hsia 1988: Attitudes Toward Woman's Familial Roles: Changes in the United States, 1977-1985. In: Gender \& Society 2,1: 39-57 [doi: 10.1177/089124388002001004].

Mason, Karen Oppenheim et al. 1973: Some Methodological Issues in Cohort Analysis of Archival Data. In: American Sociological Review 38: 282-258.

Mays, Anja 2012: Determinanten traditionell-sexistischer Einstellungen in Deutschland - eine Analyse mit ALLBUS-Daten. In: Kölner Zeitschrift für Soziologie und Sozialpsychologie 64,2: 277-302 [doi: 10.1007/s11577-012-0165-6]. 
Nave-Herz, Rosemarie 1997: Die Geschichte der Frauenbewegung in Deutschland. Hannover: Niedersächsische Landeszentrale für politische Bildung.

Peuckert, Rüdiger 2012: Familienformen im sozialen Wandel. Wiesbaden: VS-Verlag [doi: 10.1007/978-3-531-19031-0].

Pritchard, Rosalind 2003: Gender and Education in East Germany after Unification. In: Kolinsky, Eva; Nickel, Hildegard M. (Eds.): Reinventing Gender: Women in Eastern Germany since Unification. London: Frank Cass: 78-99.

Ryder, Norman B. 1965: The cohort as a concept in the study of social change. In: American Sociological Review 30,6: 843-861 [doi: 10.2307/2090964].

Schafer, Joseph L.; Graham, John W. 2002: Missing Data: Our View of the State of the Art. In: Psychological Methods 7,2: 147-177.

Swim, Janet K. et al. 1995: Sexism and Racism: Old-Fashioned and Modern Prejudices. In: Journal of Personality and Social Psychology 68: 199-241.

Tallichet, Suzanne E.; Willits, Fern K. 1986: Gender-Role Attitude Change of Young Women: Influential Factors from a Panel Study. In: Social Psychology Quarterly 49,3: 219-227 [doi: 10.2307/2786804].

Thornton, Arland; Alwin, Duane F.; Camburn, Donald 1983: Causes and Consequences of Sex-Role Attitudes and Attitude Change. In: American Sociological Review 48,2: 211-227 [doi: 10.2307/2095106].

Thornton, Arland; Young-DeMarco, Linda 2001: Four Decades of Trends in Attitudes Toward Family Issues in the United States: The 1960s Through the 1990s. In: Journal of Marriage and Family 63,4: 1009-1037 [doi: 10.1111/j.1741-3737.2001.01009.x].

Valentova, Marie 2013: Age and Sex Differences in Gender Role Attitudes in Luxem burg between 1999 and 2008. In: Work, Employment and Society 27,4: 639-657 [doi: $10.1177 / 0950017013481638]$.

Vespa, Jonathan 2009: Gender Ideology Construction: A Life Course and Intersectional Approach. In: Gender and Society 23,3: 363-387 [doi: 10.1177/0891243209337507].

Wenzel, Stefanie 2010: Konvergenz oder Divergenz? Einstellungen zur Erwerbstätigkeit von Müttern in Ost- und Westdeutschland. In: Gender - Zeitschrift für Geschlecht, Kultur und Gesellschaft 2,3: 59-76.

Winship, Christopher; Harding, David J. 2008: A Mechanism-Based Approach to the Identification of Age-Period-Cohort Models. In: Sociological Methods and Research 36: 362-401 [doi: 10.1177/0049124107310635].

Yang, Yang et al. 2008: The Intrinsic Estimator for Age-Period-Cohort Analysis: What It Is and How to Use It. In: American Journal of Sociology 113,6: 1697-1736 [doi: 10.1086/587154].

Yang, Yang; Land, Kenneth C. 2013: Age-Period-Cohort Analysis: New Models, Methods, and Empirical Applications. Boca Raton/London/New York: CRC Press. 
* This article contains supplementary material in the form of a Data Appendix:

URL: http://www.comparativepopulationstudies.de/index.php/CPoS/article/view/318/303.

Prof. Dr. Daniel Lois $(\bowtie)$. Universität der Bundeswehr München, Fakultät für Humanwissenschaften. Neubiberg, Germany.

E-mail: daniel.lois@unibw.de

URL: https://www.unibw.de/hum-bildungswissenschaft/professuren/swm/personen/profdr-daniel-lois 


\section{Appendix}

Tab. A1: Employment status and familial living arrangements mediating period and cohort effects on traditional gender ideology (unstandardised specific indirect effects)

\begin{tabular}{lllll}
\hline Indirect effect (mechanism) & \multicolumn{2}{c}{ West German } & \multicolumn{2}{c}{ East German } \\
& Women & Men & Women & Men \\
\hline Employment status & & & & \\
Year $\rightarrow$ full-time employed $\rightarrow$ TGI & $-.001^{* *}$ & & -.000 & \\
Year $\rightarrow$ part-time employed $\rightarrow$ TGI & $-.001^{* *}$ & & -.000 & \\
Year $\rightarrow$ in education $\rightarrow$ TGI & $-.0004^{* *}$ & $-.0002^{* *}$ & $-.0005^{* *}$ & $-.0002^{* *}$ \\
Year $\rightarrow$ partner in education $\rightarrow$ TGI & $-.0001^{*}$ & $-.0003^{* *}$ & -.000 & $-.0003^{* *}$ \\
Year $\rightarrow$ full-time partner $\rightarrow$ TGI & & $-.0005^{* *}$ & & -.000 \\
Year $\rightarrow$ part-time partner $\rightarrow$ TGI & & $-.0005^{* *}$ & & .000 \\
Familial living arragement & & & & \\
C1926-30 $\rightarrow$ unmarried, children $\rightarrow$ TGI & $-.003^{*}$ & .000 & -.000 & -.000 \\
C1946-50 $\rightarrow$ unmarried, children $\rightarrow$ TGI & -.002 & -.001 & -.002 & -.000 \\
C1976-80 $\rightarrow$ unmarried, children $\rightarrow$ TGI & $-.007^{*}$ & $-.008+$ & -.004 & -.001 \\
C1926-30 $\rightarrow$ unmarried, no child $\rightarrow$ TGI & $.053^{* *}$ & $.036^{* *}$ & .003 & -.002 \\
C1946-50 $\rightarrow$ unmarried, no child $\rightarrow$ TGI & $.068^{* *}$ & $.023^{*}$ & .005 & -.001 \\
C1976-80 $\rightarrow$ unmarried, no child $\rightarrow$ TGI & $.050^{* *}$ & -.002 & .000 & .005 \\
C1926-30 $\rightarrow$ married, no child $\rightarrow$ TGI & -.006 & -.009 & .009 & -.008 \\
C1946-50 $\rightarrow$ married, no child $\rightarrow$ TGI & -.007 & -.004 & .016 & -.004 \\
C1976-80 $\rightarrow$ married, no child $\rightarrow$ TGI & -.006 & -.001 & .009 & .002 \\
\hline
\end{tabular}

** $\mathrm{p} \leq .01 ; * \mathrm{p} \leq .05 ;+\mathrm{p} \leq .10$

References: non-working (including small-scale employment), married with children, cohort 1906-1910

Source: GGSS (1982-2016, own calculations) 
Tab. A2: Employment status and familial living arrangements mediating period and cohort effects on negative evaluation of mother's gainful employment (unstandardised specific indirect effects)

\begin{tabular}{lcccc}
\hline Indirect effect (mechanism) & \multicolumn{2}{c}{ West German } & \multicolumn{2}{c}{ East German } \\
& Women & Men & Women & Men \\
\hline Employment status & & & & \\
Year $\rightarrow$ full-time employed $\rightarrow$ E. & $-.0005^{* *}$ & & -.000 & \\
Year $\rightarrow$ part-time employed $\rightarrow$ E. & $-.001^{* *}$ & & .000 & \\
Year $\rightarrow$ in education $\rightarrow$ EMPLOY & $-.0002^{* *}$ & .000 & $-.0003^{* *}$ & .000 \\
Year $\rightarrow$ partner in education $\rightarrow$ E. & -.000 & $-.0001^{* *}$ & -.000 & -.000 \\
Year $\rightarrow$ full-time partner $\rightarrow$ EMPLOY & & $-.0005^{* *}$ & & -.000 \\
Year $\rightarrow$ part-time partner $\rightarrow$ EMPOY & & $-.0005^{* *}$ & & -.000 \\
Familial living arragement & & & & \\
C1926-30 $\rightarrow$ unmarried, children $\rightarrow$ E. & $-.003^{*}$ & .000 & -.000 & -.000 \\
C1946-50 $\rightarrow$ unmarried, children $\rightarrow$ E. & -.002 & -.001 & -.002 & -.001 \\
C1976-80 $\rightarrow$ unmarried, children $\rightarrow$ E. & $-.009^{*}$ & $-.009^{*}$ & -.006 & -.006 \\
C1926-30 $\rightarrow$ unmarried, no child $\rightarrow$ E. & .005 & $.025^{* *}$ & -.005 & .002 \\
C1946-50 $\rightarrow$ unmarried, no child $\rightarrow$ E. & .006 & $.016^{*}$ & -.008 & .001 \\
C1976-80 $\rightarrow$ unmarried, no child $\rightarrow$ E. & .004 & -.002 & -.000 & -.005 \\
C1926-30 $\rightarrow$ married, no child $\rightarrow$ E. & .009 & .003 & -.002 & -.012 \\
C1946-50 $\rightarrow$ married, no child $\rightarrow$ E. & .012 & .001 & -.004 & -.006 \\
C1976-80 $\rightarrow$ married, no child $\rightarrow$ E. & .010 & .000 & -.002 & .003 \\
\hline
\end{tabular}

$* * p \leq .01 ; * p \leq .05 ;+p \leq .10$

References: non-working (including small-scale employment), married with children, cohort 1906-1910

Source: GGSS (1982-2016, own calculations) 


\section{Comparative Population Studies}

WWW.comparativepopulationstudies.de

ISSN: 1869-8980 (Print) - 1869-8999 (Internet)

\section{Published by}

Prof. Dr. Norbert F. Schneider

Federal Institute for Population Research D-65180 Wiesbaden / Germany

\section{(cc) BY-SA}

2020

\section{Managing Editor}

Prof. Dr. Johannes Huinink

Dr. Katrin Schiefer

\section{Editorial Assistant}

Beatriz Feiler-Fuchs

Wiebke Hamann

\section{Layout}

Beatriz Feiler-Fuchs

E-mail:cpos@bib.bund.de

\section{Scientific Advisory Board}

Karsten Hank (Cologne)

Michaela Kreyenfeld (Berlin)

Marc Luy (Vienna)

Natalie Nitsche (Rostock)

Zsolt Spéder (Budapest)

Rainer Wehrhahn (Kiel)

\section{Board of Reviewers}

Bruno Arpino (Barcelona)

Kieron Barclay (Rostock)

Laura Bernardi (Lausanne)

Gabriele Doblhammer (Rostock)

Anette Eva Fasang (Berlin)

Michael Feldhaus (Oldenburg)

Tomas Frejka (Sanibel)

Alexia Fürnkranz-Prskawetz (Vienna)

Birgit Glorius (Chemnitz)

Fanny Janssen (Groningen)

Frank Kalter (Mannheim)

Stefanie Kley (Hamburg)

Bernhard Köppen (Koblenz)

Anne-Kristin Kuhnt (Duisburg)

Hill Kulu (St Andrews)

Nadja Milewski (Rostock)

Roland Rau (Rostock)

Thorsten Schneider (Leipzig)

Tomas Sobotka (Vienna)

Jeroen J. A. Spijker (Barcelona)

Heike Trappe (Rostock)

Helga de Valk (The Hague)

Sergi Vidal (Barcelona)

Michael Wagner (Cologne) 